\title{
KALKULASI OVERALL EQUIPMENT EFFECTIVENESS (OEE) UNTUK MENGETAHUI EFEKTIVITAS MESIN KOMATZU 80T (Studi Kasus pada PT. Yogya Presisi Tehnikatama Industri)
}

\author{
Sunaryo dan Eko Ardi Nugroho \\ Teknik Industri, Fakultas Teknologi Industri, Universitas Islam Indonesia \\ Jalan Kaliurang Km. 14,5 Yogyakarta, Sleman, 55584
}

\begin{abstract}
One of the molding injection Komatsu 80T in the PT Yogya Presisi Teknikatama Industry has a problem on its performance. The performance of this injecton molding can be calculated by Overall Equipment Effectiveness(OEE). OEE is a factor which can be found by multiplication of Availability Ratio, Performance Efficiency and Rate of Quality. The values of OEE then be compared to the standart values of JIPM (The Japan Institute of Plan Maintenance) which JIPM defined a minimal standard value of OEE is $85 \%$. If the result of OEE calculation less than 85\%, what causes it be analysed by the Six Big Losses Analysis. The Result of analysis showed the sequence as Reduced Speed Loss, Setup and Adjusmnet loss, and Rework Loss. Then by Fishbone diagram, it can be known the causes of the decreasing OEE values, so the management can do the repairment.
\end{abstract}

Keywords: Injection Mold, Overall Equipment Effectiveness (OEE), Six Big Loss

\section{PENDAHULUAN}

\subsection{Latar Belakang Masalah}

Peralatan atau mesin produksi sebagai salah satu sistem memegang peranan penting dalam proses produksi, harus selalu dalam keadaan reliable (handal). Kehandalan diartikan secara umum sebagai suatu peluang dari suatu sistem peralatan untuk dapat tampil sesuai dengan yang ditetapkan. Kehandalan merupakan syarat utama agar suatu sistem peralatan dapat bekerja dengan baik, serta proses produksi dapat berjalan sesuai dengan rencana. Acap kali kegagalan berproduksi bersumber pada ketidaksesuaian antara aktifitas pelaksanaan dengan rencana, sebagai akibat dari peralatan yang tidak menunjang. Salah satu metode yang digunakan adalah Total Productive Maintenance (TPM), dimana dengan TPM ini memungkinkan perusahaan untuk memiliki program pemeliharaan peralatan produksi sehingga proses produksi dapat berjalan dengan efektif dan efisien(Stephens,Matteew,2004) a. Dengan menerapkan strategi TPM maka memungkinkan sebuah perusahaan untuk menemukan pemborosan yang timbul dan terjadi pada proses produksi. Total Productive Maintenance memungkinkan perusahaan memiliki program pemeliharaan pada peralatan produksi sehingga nantinya proses produksi dapat berjalan dengan seefektif dan seefisien mungkin. Dengan menerapkan metode TPM juga memungkinkan sebuah perusahaan untuk menemukan dan menghilangkan faktor utama yang menghambat proses produksi. Perhitungan Overall Equipment Effectiveness (OEE) pada mesin produksi bisa digunakan sebagai dasar perenapan pada metode Total Productive Maintenance, dimana selanjutnya akan dilakukan penghitungan nilai faktor Six Big Losses dan penghapusan nilai faktor terbesar Six Big Losses sebagai tahapan akhir dari metode Total Productive Maintenance yang digunakan. 


\subsection{Rumusan Masalah}

Perusahaan ini memproduksi produk diskrit berupa komponen mobil yang berbahan baku plastik dengan alat produksi berupa mesin injeksi Komatsu 80T. Apakah mesin injeksi Komatsu 80T memenuhi kehandalan menurut perhitumgam OEE

Faktor Six Big Losses apakah yang memiliki pengaruh terbesar terhadap rendahnya nilai Overall Equipment Effectiveness (OEE) pada mesin Komatzu 80T (Injection Machine)?

\subsection{Batasan Masalah}

Batasan masalah ditetapkan berdasar data yang diambil selama bulan April hingga Oktober 2014 dari rekapan yang dimiliki perusahaan, baik produk yang baik, cacat maupun rework.

\subsection{Tujuan Penelitian}

Melakukan perhitungan nilai Availability Ratio, Performance Ratio, dan Quality Ratio untuk mendapatkan nilai OEE sehingga bisa diketahui kinerja mesin injeksi dan menentukan faktor utama penyebab menurunnya kinerja mesin.

\subsection{Manfaat Penelitian}

Melalui hasil penelitian ini dapat dibuat strategi manajemen perawatan mesin Komatzu 80T (Injection Machine).

\section{TINJAUAN PUSTAKA}

\subsection{Overall Equipment Effectiveness (OEE)}

Overall Equipment Effectiveness (OEE) merupakan metode yang digunakan sebagai alat ukur (metric) dalam penerapan metode Total Productive Maintenance. Overall Equipment Effectiveness berguna untuk menjaga mesin atau peralatan tetap dalam kondisi ideal dengan menghapuskan Six Big Losses pada mesin atau peralatan. The Six Big Losses merupakan penyebab peralatan produksi tidak beroperasi dengan normal (Denso, 2006), yaitu: Start up Loss, Set up or Adjaustment Loss,Cycle Time Losses, Speed
Loss, Breakdown Loss dan Defect Loss. Dengan analisis OEE ini akan diperoleh tingkat kehandalan peralatan produksi melalui parameter :

1. Availability Rate untuk mengukur efektivitas maintenance peralatan produksi dalam kondisi produksi sedang berlangsung,

2. Performance Rate untuk mengukur seberapa efektif peralatan produksi yang digunakan.

3. Quality Rate untuk mengukur efektivitas proses manufaktur untuk mengeliminasi scrap, rework, dan yield loss.

Nilai Overall Equipment Effectiveness (OEE) dikatakan memenuhi standard JIPM bila, nilai Availability rasio sebesar 90\%, nilai Performance rasio sebesar 95\%, nilai Quality rasio sebesar $99 \%$ dan nilai Overall Equipment Effectiveness (OEE) sebesar 85\%. Nilai Overall Equipment Effectiveness (OEE) diperoleh dari perkalian tiga parameter diatas,yaitu sebagai berikut (Nakajima,1998) :

$O E E=$ Availability rate $x$ Performance rate $x$

Quality rate (\%)

Availability Rasio merupakan suatu rasio yang menggambarkan pemanfaatan waktu operasi mesin yang tersedia dan dirumuskan(Nakajima, 1988):

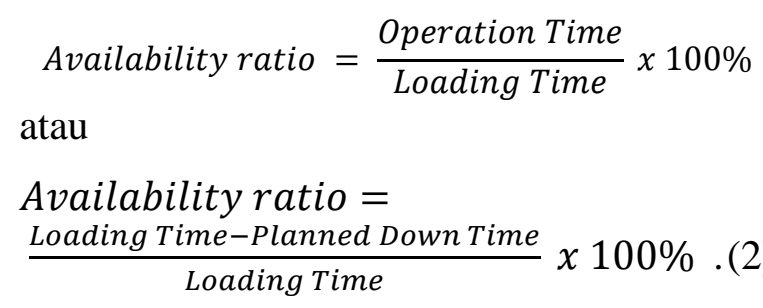

Loading Time adalah waktu yang tersedia per periode waktu

Downtine mesin adalah waktu proses yang seharusnya digunakan mesin akan tetapi karena adanya gangguan pada mesin atau peralatan mengakibatkan tidak ada Output yang dihasilkan. Operation time waktu aktifitas mesin berproduksi sesungguhnya. 
Performance efficiency merupakan suatu ratio yang menggambarkan kemampuan dari peralatan dalam menghasilkan barang dan dapat dihitung melalui rumus.

Performance Efficiency $=$

$\frac{\text { Processed Amount x Ideal Cycle Time }}{\text { Operation Time }} \times 100 \%$. (3)

Ideal Cycle adalah waktu siklus ideal atau waktu standar, Processed Amount adalah jumlah produk yang diproses dan Operation Time adalahwaktu operasi mesin.

Rate of quality product merupakan suatu rasio yang menggambarkan kemampuan peralatan dalam menghasilkan produk yang sesuai dengan standar atau rasio jumlah produk yang baik terhadap jumlah produk yang diproses dan dihitung dari rumus;

Quality Rate $=$

$\frac{\text { Processed Amount-Defect Amount }}{\text { Processed Amount }} \times 100 \%$

\subsection{Faktor penurun Efisiensi Mesin injeksi}

Dari sekian banyak faktor penyebab menurunnya kinerja mesindan berakibat pada menurunnya produktifitas, diambil enam faktor yang disebut sebagai enam kerugian besar (six big losses). Terdapat 6 faktor yang terbagi dalam 3 jenis kerugian dalam Six Big Losses, yaitu:

\section{Downtime Loss (Penurunan Waktu)}

Downtime Loss terdiri dari 2 kerugian, yaitu :

Equipment Failures Loss (Breakdown) yaitu merupakan kerusakan mesin atau peralatan secara tiba - tiba dan dirumuskan:

Breakdown Loss $=$

$\frac{\text { Total Breakdown Time }}{\text { Loading Time }} \times 100 \%$

Setup And Adjustment Loss adalah kerugian karena pemasangan dan penyetelan /set up dan waktu penyelesaian (Adjustment

Setup and Adjustment loss $=$ Total set up and adjustment time $x$ 100\%
Speed Loss (Penurunan Kecepatan)

Speed Loss terdiri dari 2 kerugian, yaitu Idling atau Minor Stoppage Loss dan Reduced Speed Loss. Mesin tak berproduksi karena mesin berhenti dirumuskan:

Idling/M.S.L $=$

$\frac{\text { Non productive time }}{\text { Loading time }} \times 100 \%$

Reduced Speed Loss(RSL) terjadi jika kecepatan aktual operasi mesin lebih kecil dari kecepatan nominalnya dan dirumuskan:

$\mathrm{RSL}=$

$\frac{\text { (Ideal Production Time } x \text { Total Product Process) }}{100 \%}$

Defect Loss (Cacat)

Defect Loss terdiri dari 2 kerugian, yaitu Rework Loss dan Reduced Yield Loss. Rework Loss yaitu kerugian yang disebabkan karena adanya produk cacat maupun karena kerja produk sehingga harus diproses ulang dan dirumuskan:

Rework Loss $=$

$\frac{\text { Ideal cycle time } x \text { rework }}{\text { Loading time }} \times 100 \%$

Reduced Yield Loss adalah kerugian pada awal waktu produksi hingga mencapai kondisi produksi yang sesuai dengan spesifikasi produk yang diinginkan. Rumus untuk menghitung Reduced Yield Loss adalah:

Yield / scrap loss $=$

$\frac{\text { ideal cycle time } x \text { scrap }}{\text { Loading time }} \times 100 \%$

\section{METODOLOGI PENELITIAN}

\subsection{Pengambilan Data}

Untuk bisa membuat analisa dibutuhkan data-data sebagai berikut:

Data Downtime, Data Planned Downtime, Data Set-Up, Data produksi mesin komatzu 80T, Data pengukuran satu siklus operasi mesin komatzu 80T, Data Sekunder 
Data tersebut diperoleh dengan pengamatan dan pengukuran dilapangan terhadap perilaku dan kondisi mesin produksi berupa mesin cetak komatzu 80T

\subsection{Pengolahan Data}

Untuk mengetahui nilai OEE perlu dilakukan terlebih dulu penghitungan parameter-parameter dari rumus yang telah ditulis pada bab Tinjauan Pustaka. Parameter - parameter tersebut adalah Available Ratio, Performance Efficiency, Rate of QualityProduct,. Kemudian juga dihitung faktor-faktor yang menjadi penyebab menurunnya nilai OEE yaitu Down time Loss (kehilangan waktu akibat set up mesin dan kerusakan mesin yang terjadi secara mendadak), Speed Losses, Defect Loss (kehilangan yang disebabkan oleh adanya Rework loss Reduced Yield Loss. Kemudian dari parameter penyebab penurunan OEE tersebut dicari nilai yang terbesar. Dari nilai Six Big Loss terbesar ini kemudian dicari sumber penyebabnya menggunakan Diagram Fish Bone.

\subsection{Data Produksi Mesin Komatzu 80T}



Tabel 4.1 Data Produksi Mesin Komatzu 80T Pada Bulan Januari - Oktober 2014

\begin{tabular}{|c|c|c|c|c|c|c|}
\hline \multirow[b]{2}{*}{ Bulan } & \multirow{2}{*}{$\begin{array}{c}\text { Total } \\
\text { Available } \\
\text { Time } \\
\text { (Jam) }\end{array}$} & \multirow{2}{*}{$\begin{array}{c}\text { Total } \\
\text { Product } \\
\text { Processed } \\
\text { (Kg) }\end{array}$} & \multirow{2}{*}{$\begin{array}{c}\text { Good } \\
\text { Product } \\
\text { (Kg) }\end{array}$} & \multirow[b]{2}{*}{$\begin{array}{c}\text { Waste } \\
\text { (Kg) }\end{array}$} & \multicolumn{2}{|c|}{ Rework } \\
\hline & & & & & $\begin{array}{c}\text { Not Good } \\
\text { Product } \\
\text { (Kg) }\end{array}$ & $\begin{array}{l}\text { Runner } \\
\text { (Kg) }\end{array}$ \\
\hline Januari & 431,14 & 922,71 & 463,68 & 30,77 & 3,43 & 424,83 \\
\hline Februari & 330,13 & 746,97 & 417,64 & 23,44 & 16,25 & 289,64 \\
\hline Maret & 304,28 & 939,25 & 708,95 & 9,07 & 39,18 & 182,05 \\
\hline April & 312,09 & 972,3 & 715,55 & 10,12 & 38,42 & 208,21 \\
\hline Mei & 357,49 & 1137,31 & 849,47 & 19,51 & 27,48 & 240,85 \\
\hline Juni & 372,45 & 1145,8 & 859 & 12,52 & 32,61 & 241,67 \\
\hline Juli & 359 & 1074,32 & 768,61 & 32,75 & 53,14 & 219,82 \\
\hline Agustus & 404,4 & 1009,37 & 831,71 & 36,46 & 32,19 & 109,01 \\
\hline September & 284,61 & 725,66 & 541,86 & 14,65 & 41,66 & 127,49 \\
\hline Oktober & 241,93 & 613,49 & 443,1 & 12,55 & 46,41 & 111,43 \\
\hline
\end{tabular}


Tabel 4.2 Data Delay Mesin Komatzu 80T Pada Bulan Januari - Oktober 2014

\begin{tabular}{ccccccc}
\hline Bulan & $\begin{array}{c}\text { Setting and } \\
\text { adjustment } \\
\text { (Jam) }\end{array}$ & $\begin{array}{c}\text { Breakdown } \\
\text { Mesin (Jam) }\end{array}$ & $\begin{array}{c}\text { Pembersihan } \\
\text { Mesin (Jam) }\end{array}$ & $\begin{array}{c}\text { Pemadaman } \\
\text { Listrik (Jam) }\end{array}$ & $\begin{array}{c}\text { Planned } \\
\text { Downtime } \\
\text { (Jam) }\end{array}$ & $\begin{array}{c}\text { Total } \\
\text { Delay } \\
\text { (Jam) }\end{array}$ \\
\hline Januari & 13,6 & 5,15 & 3,42 & 0,17 & 14,7 & 37,04 \\
Februari & 19 & 3,68 & 1,63 & 2,16 & 12,83 & 39,3 \\
Maret & 13,02 & 4,28 & 1,75 & 0,92 & 11,93 & 31,9 \\
April & 12,05 & 3,83 & 2,88 & 2,25 & 10,87 & 31,88 \\
Mei & 9,9 & 3,85 & 1,08 & 3 & 12,4 & 30,23 \\
Juni & 8,15 & 6,12 & 2,87 & 2,67 & 12,32 & 32,13 \\
Juli & 7,88 & 8,2 & 7,08 & 2,42 & 23,15 & 48,73 \\
Agustus & 4,21 & 8,61 & 7,23 & 0 & 27,18 & 47,23 \\
September & 5,28 & 5,46 & 1,96 & 2,25 & 18,71 & 33,66 \\
Oktober & 9 & 4,51 & 2,05 & 3,9 & 14,25 & 33,71 \\
\hline
\end{tabular}

Nilai Total Downtime diperoleh dari penjumlahan data-data Setting and adjusment, Breakdown mesin, Pembersihan Mesin, Pemadaman listrik dan Planned Downtime. Nilai Loading time diperoleh melalui pengurangan Availability time dengan Planned Downtime. Dari sini bisa diperoleh Nilai Availilability dan ditampilkan dalam tabel bersama dengan Nilai standard dari JIMP

\subsection{Perhitungan Availability Ratio}

Availibility Ratio menggunakan rumus (2) ditampilkan pada Tabel 4. 3

Tabel 4.3 Perhitungan Availability Ratio Bulan Januari - Oktober 2014

Bulan $\quad$ Loading Time (Jam) Total Downtime (Jam)

\begin{tabular}{ccccc}
\hline Januari & 416,44 & 22,34 & $94,64 \%$ & $90 \%$ \\
Februari & 317,3 & 26,47 & $91,66 \%$ & $90 \%$ \\
Maret & 292,35 & 19,97 & $93,17 \%$ & $90 \%$ \\
April & 301,22 & 21,01 & $93,03 \%$ & $90 \%$ \\
Mei & 345,09 & 17,83 & $94,83 \%$ & $90 \%$ \\
Juni & 360,13 & 19,81 & $94,50 \%$ & $90 \%$ \\
Juli & 335,85 & 25,58 & $92,38 \%$ & $90 \%$ \\
Agustus & 377,22 & 20,05 & $94,68 \%$ & $90 \%$ \\
September & 265,9 & 14,95 & $94,38 \%$ & $90 \%$ \\
Oktober & 227,68 & 19,46 & $91,45 \%$ & $90 \%$ \\
\hline
\end{tabular}

\section{Perhitungan Performance Efficiency}

Perhitungan Performancy Efficiency menggunakan rumus (3) dan Nilai menurut JIPM ditampilkan pada Tabel 4.4.

Tabel 4.4. Perhitungan Performance Efficiency Bulan Januari - Oktober 2014

\begin{tabular}{cccccc}
\hline Bulan & $\begin{array}{c}\text { Total Product } \\
\text { Processed }(\mathbf{K g})\end{array}$ & $\begin{array}{c}\text { Operation Time } \\
(\mathbf{J a m})\end{array}$ & $\begin{array}{c}\text { Ideal Cyle Time } \\
(\mathbf{K g} / \mathbf{J a m})\end{array}$ & $\begin{array}{c}\text { Performance } \\
\text { Efficiency }(\%)\end{array}$ & $\begin{array}{c}\text { JIMP } \\
(\%)\end{array}$ \\
\hline Januari & 922,71 & 394,1 & 0,412549 & $96,59 \%$ & $95 \%$ \\
Februari & 746,97 & 290,83 & 0,374215 & $96,11 \%$ & $95 \%$ \\
Maret & 939,25 & 272,38 & 0,278627 & $96,08 \%$ & $95 \%$ \\
April & 972,3 & 280,21 & 0,278155 & $96,52 \%$ & $95 \%$ \\
Mei & 1137,31 & 327,26 & 0,277768 & $96,53 \%$ & $95 \%$ \\
Juni & 1145,8 & 340,32 & 0,287190 & $96,69 \%$ & $95 \%$ \\
Juli & 1074,32 & 310,27 & 0,270182 & $93,55 \%$ & $95 \%$ \\
Agustus & 1009,37 & 357,17 & 0,330072 & $93,28 \%$ & $95 \%$ \\
September & 725,66 & 250,95 & 0,323089 & $93,43 \%$ & $95 \%$ \\
Oktober & 613,49 & 208,22 & 0,319411 & $94,11 \%$ & $95 \%$ \\
\hline
\end{tabular}


Perhitungan Rate of Quality Product

Perhitungan Rate of Quality menggunakan rumus (3) dan Nilai menurut JIPM ditampilkan pada Tabel 4.5.

Tabel 4.5 Perhitungan Rate Of Quality Product Bulan Januari - Oktober 2014

\begin{tabular}{ccccc}
\hline Bulan & $\begin{array}{c}\text { Total Product } \\
\text { Processed } \\
\text { (Kg) }\end{array}$ & $\begin{array}{c}\text { Total Defect } \\
\text { Amount } \\
\text { (Kg) }\end{array}$ & $\begin{array}{c}\text { Rate Of } \\
\text { Quality } \\
\text { Product }(\%)\end{array}$ & $\begin{array}{c}\text { JIMP } \\
(\%)\end{array}$ \\
\hline Januari & 922,71 & 459,03 & $50,25 \%$ & $99 \%$ \\
Februari & 746,97 & 329,33 & $55,91 \%$ & $99 \%$ \\
Maret & 939,25 & 230,30 & $75,48 \%$ & $99 \%$ \\
April & 972,3 & 256,75 & $73,59 \%$ & $99 \%$ \\
Mei & 1137,31 & 287,84 & $74,69 \%$ & $99 \%$ \\
Juni & 1145,8 & 286,80 & $74,97 \%$ & $99 \%$ \\
Juli & 1074,32 & 305,71 & $71,54 \%$ & $99 \%$ \\
Agustus & 1009,37 & 177,66 & $82,40 \%$ & $99 \%$ \\
September & 725,66 & 183,80 & $74,64 \%$ & $99 \%$ \\
Oktober & 613,49 & 170,39 & $72,23 \%$ & $99 \%$ \\
\hline
\end{tabular}

Perhitungan Overall Equipment Effectiveness (OEE)

Perhitungan OEE menggunakan rumus (3) dan Nilai menurut JIPM ditampilkan pada Tabel 4.6

Tabel 4.6 Perhitungan Overall Equipment Effectiveness Bulan Januari - Oktober 2014

\begin{tabular}{cccccc}
\hline Bulan & $\begin{array}{c}\text { Availability } \\
(\%)\end{array}$ & $\begin{array}{c}\text { Performance } \\
\text { Efficiency } \\
(\%)\end{array}$ & $\begin{array}{c}\text { Rate Of } \\
\text { Quality } \\
\text { Product }(\%)\end{array}$ & OEE (\%) & $\begin{array}{c}\text { JIMP } \\
(\%)\end{array}$ \\
\hline Januari & $94,64 \%$ & $96,59 \%$ & $50,25 \%$ & $45,93 \%$ & $85 \%$ \\
Februari & $91,66 \%$ & $96,11 \%$ & $55,91 \%$ & $49,26 \%$ & $85 \%$ \\
Maret & $93,17 \%$ & $96,08 \%$ & $75,48 \%$ & $67,57 \%$ & $85 \%$ \\
April & $93,03 \%$ & $96,52 \%$ & $73,59 \%$ & $66,08 \%$ & $85 \%$ \\
Mei & $94,83 \%$ & $96,53 \%$ & $74,69 \%$ & $68,38 \%$ & $85 \%$ \\
Juni & $94,50 \%$ & $96,69 \%$ & $74,97 \%$ & $68,50 \%$ & $85 \%$ \\
Juli & $92,38 \%$ & $93,55 \%$ & $71,54 \%$ & $61,83 \%$ & $85 \%$ \\
Agustus & $94,68 \%$ & $93,28 \%$ & $82,40 \%$ & $72,78 \%$ & $85 \%$ \\
September & $94,38 \%$ & $93,43 \%$ & $74,67 \%$ & $65,84 \%$ & $85 \%$ \\
Oktober & $91,45 \%$ & $94,11 \%$ & $72,23 \%$ & $62,16 \%$ & $85 \%$ \\
\hline
\end{tabular}

\section{Perhitungan Six Big Losses}

Perhitungan Six Big Losses menggunakan rumus-rumus (5),(6),(7),(8),(9), dan 10 ditampilkan pada Tabel 4.7 dan chart pada Gambar 4. 1 


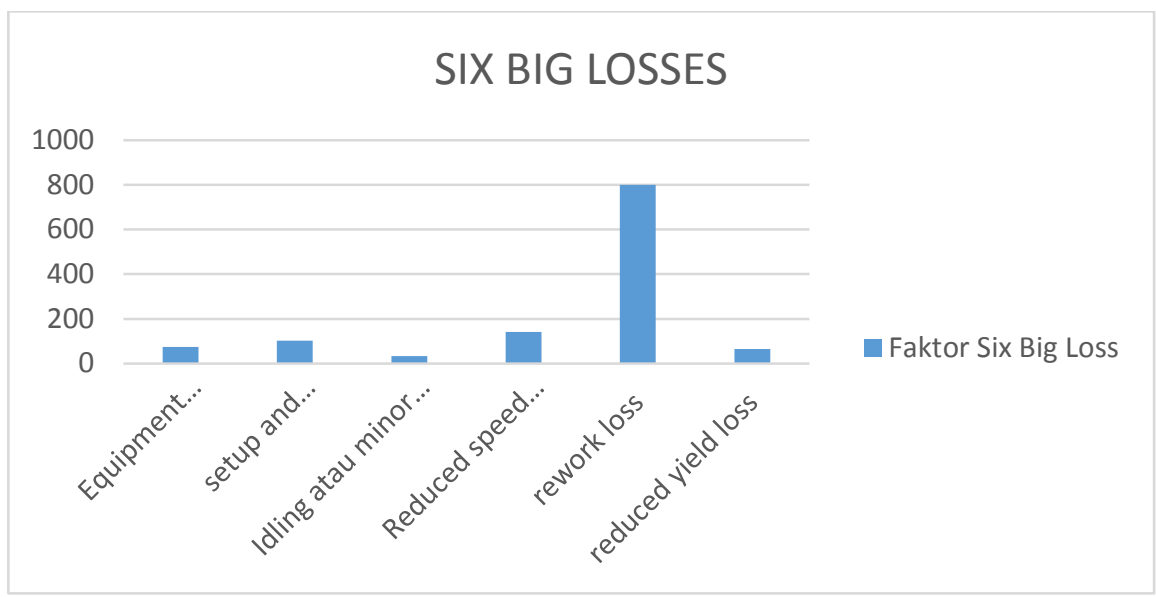

Gambar 4.1. Time Loss Six Big Losses Mesin Komatzu 80T

Tabel 4.7. Pengurutan Presentase Faktor Six Big Losses Mesin Komatzu 80T

\begin{tabular}{clccc}
\hline No & \multicolumn{1}{c}{ Faktor Six Big Loss } & $\begin{array}{c}\text { Time Loss } \\
(\mathbf{J a m})\end{array}$ & $\begin{array}{c}\text { Persentase } \\
(\boldsymbol{\%})\end{array}$ & $\begin{array}{c}\text { Persentase } \\
\text { Komulatif }(\boldsymbol{\%})\end{array}$ \\
\hline 1 & Rework Loss & 800,11 & $65,93 \%$ & $66 \%$ \\
2 & Reduced Speed Losses & 140,56 & $11,58 \%$ & $78 \%$ \\
3 & Set up and Adjustment Loss & 102,09 & $8,41 \%$ & $86 \%$ \\
4 & Breakdown Loss & 73,43 & $8,19 \%$ & $92 \%$ \\
5 & Screp / yield loss & 65,45 & $6,05 \%$ & $97 \%$ \\
6 & Idling Minor Stoppages & 31,95 & $2,63 \%$ & $100 \%$ \\
\hline & Total & $\mathbf{1 2 1 3 , 5 3}$ \\
\hline
\end{tabular}

Secara umum penyebab dari besarnya masalah tersebut. Dibawah ini merupakan presentase rework loss adalah besarnya fishbone diagram untuk mengetahui produk cacat (Not Good), Runner dan Waste. penyebab produk cacat (Not Good), Runner Oleh karena itu perlu diketahui penyebab dan Waste tersebut.

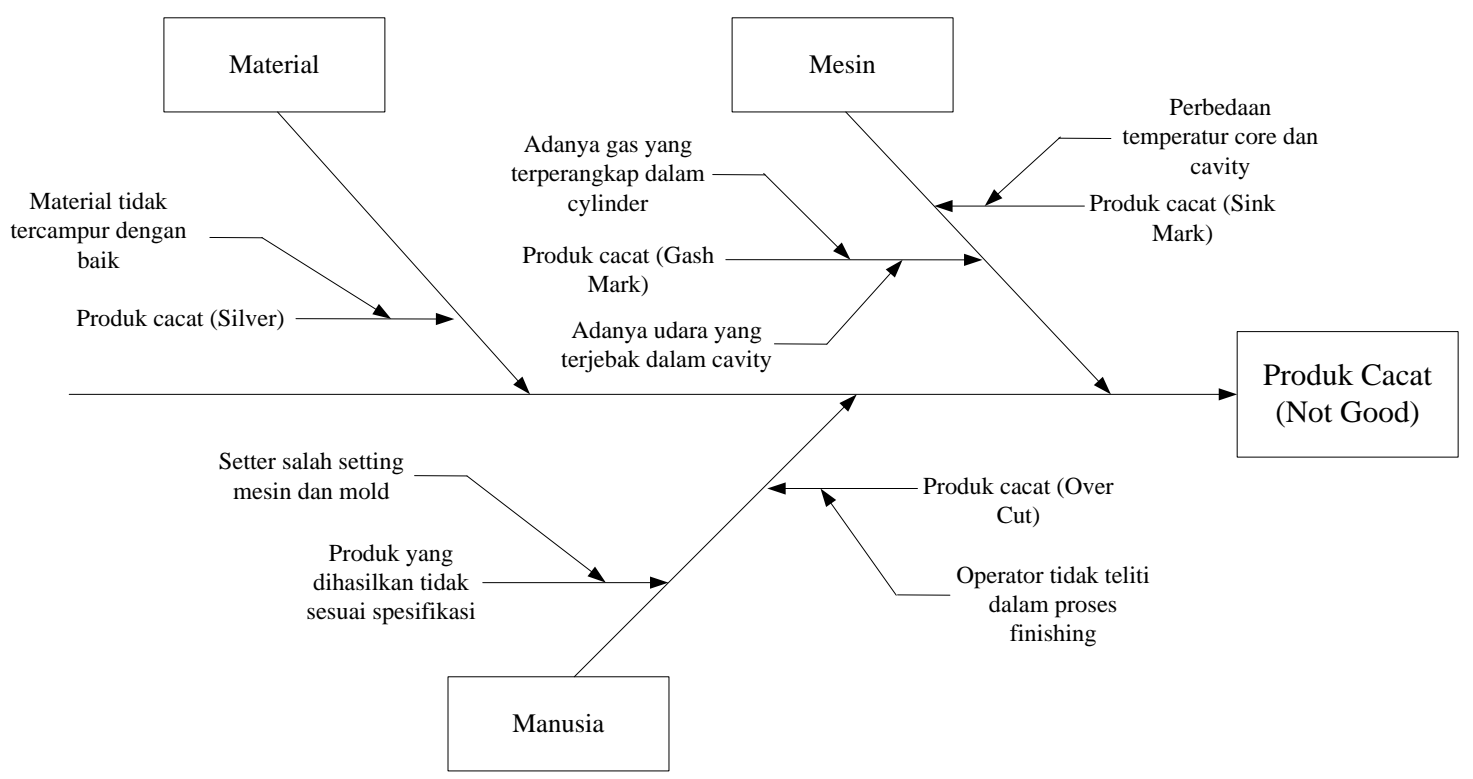

Gambar 4.2. Fishbone Diagram Produk Cacat (Not Good) 


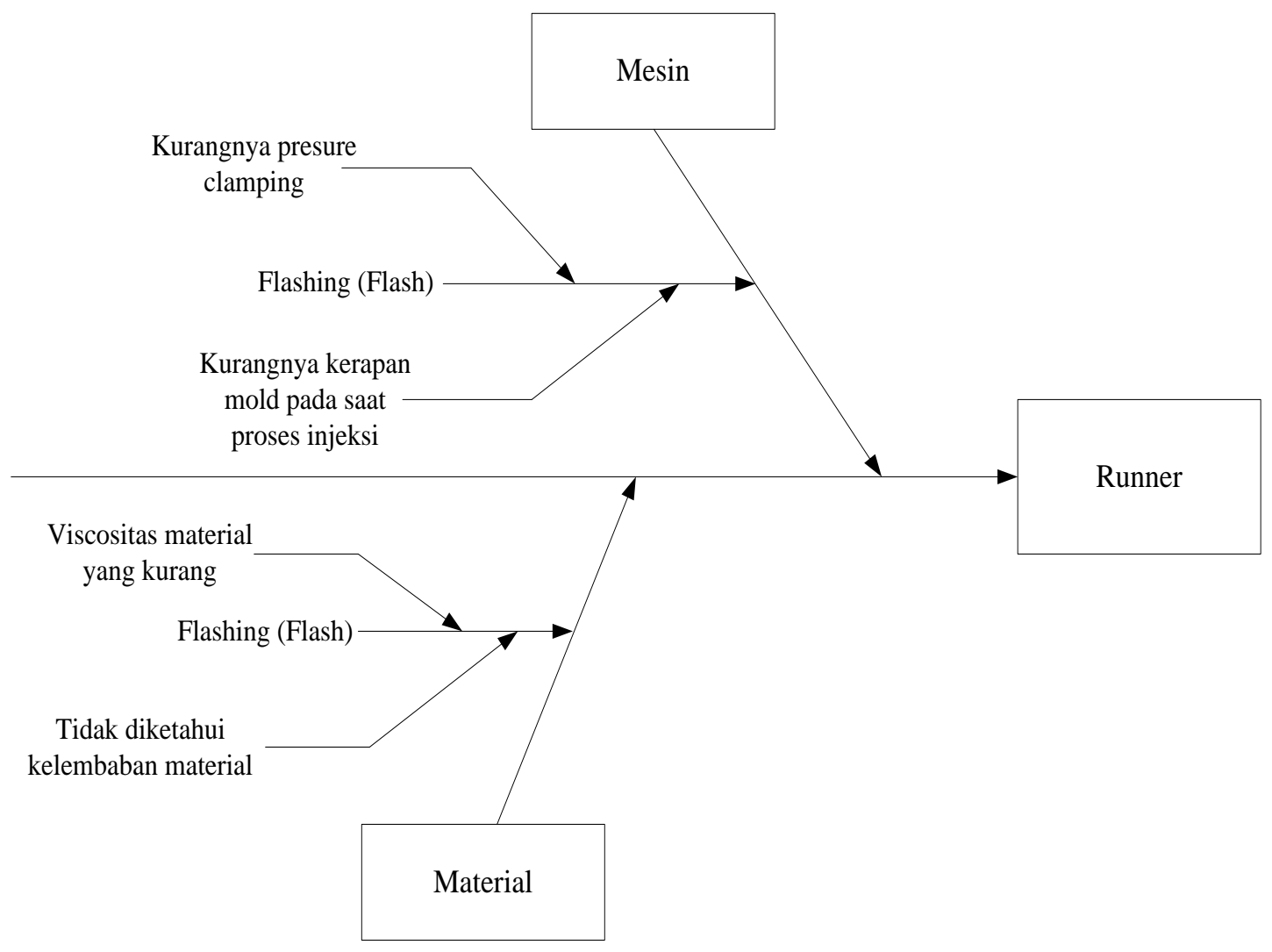

Gambar 4.3. Fishbone Diagram Runner

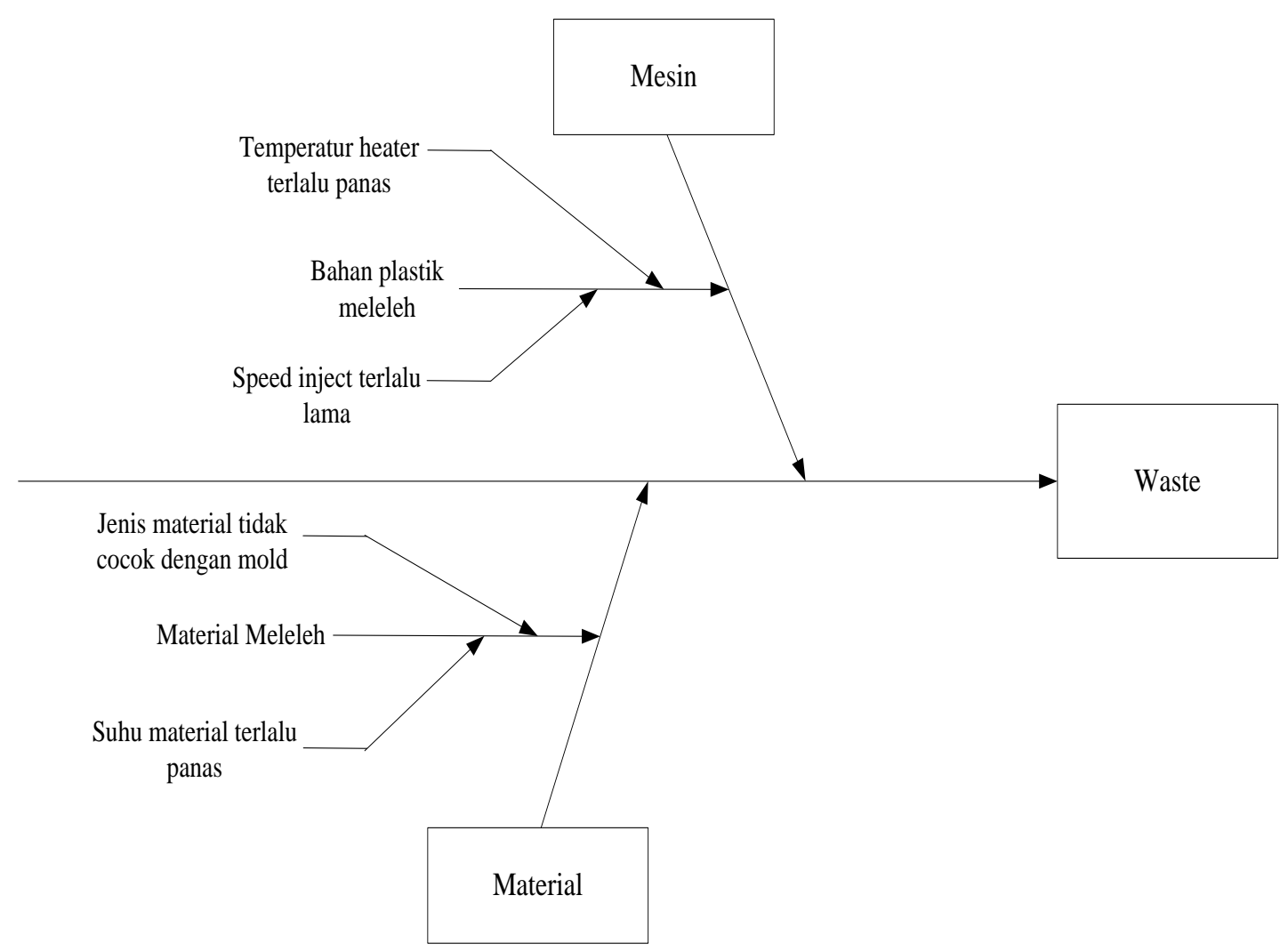

Gambar 4.4. Fishbone Diagram Waste 


\section{KESIMPULAN DAN SARAN}

Berdasarkan hasil perhitungan dan analisis yang telah dilakukan, maka dapat ditarik kesimpulan sebagai berikut. Hasil perhitungan menunjukkan nilai Overall Equipment Effectiveness (OEE) lebih kecil dari nilai standar $85 \%$. Rendahnya nilai OEE tersebut dipengaruhi oleh banyaknya produk cacat dan /waste. Dari analisis faktor six big losses faktor yang paling berpengaruh adalah Rework Loss dengan persentase total sebesar 65,93\%, dengan Time Loss sebesar 800,11 jam. Besarnya persentase rework loss dipengaruhi oleh besarnya produk rework, banyaknya produk rework karena komponenkomponen utama mesin sering mengalami masalah sehingga produk yang dihasilkan tidak sesuai spesifikasi, dari faktor manusia adalah kurang telitinya operator dalam proses finishing, salah setting mesin dan mold,

Saran atau rekomendasi yang dapat diberikan dalam penerapan Total Productive Maintenance (TPM) pada mesin Komatzu 80T adalah melakukan perawatan mesin yang bersifat Preventive Maintenance yaitu melakukan perawatan mesin secara berkala untuk komponen-komponen utama dalam mesinagar mesin dari kerusakan-kerusakan yang tidak terduga. Dengan berkurangnya kerusakan atau masalah pada mesin Komatzu 80T maka produk yang akan dihasilkan mesin juga akan memenuhi standar spesifikasi kulitas produk.

\section{DAFTAR PUSTAKA}

Corder, Anthony. Teknik Manajemen Pemeliharaan, K. Hadi. Erlangga, Jakarta. 1992.

Denso. Introductionto Total Productive Maintenance:Study Guide. Denso. 2006.

Mobley, k. Higgins, L. Wikoff,D. 'maintenance Engineering Handbook, Mc Graw Hill Handbooks. 2008.
Nakajima,S. 'Introduction to Total Productive Maintenance(TPM)', Cambridge: Productive Press Inc. 1998.

Stephens, Matteew. P. 'Productivity and Reiability-Based Maintenance Management'. Pearson Education Inc. New Jersey. 2004. 